Russian Academy of Sciences

Far Eastern Branch

Botanical Garden-Institute

Institute of Biology and Soil Science

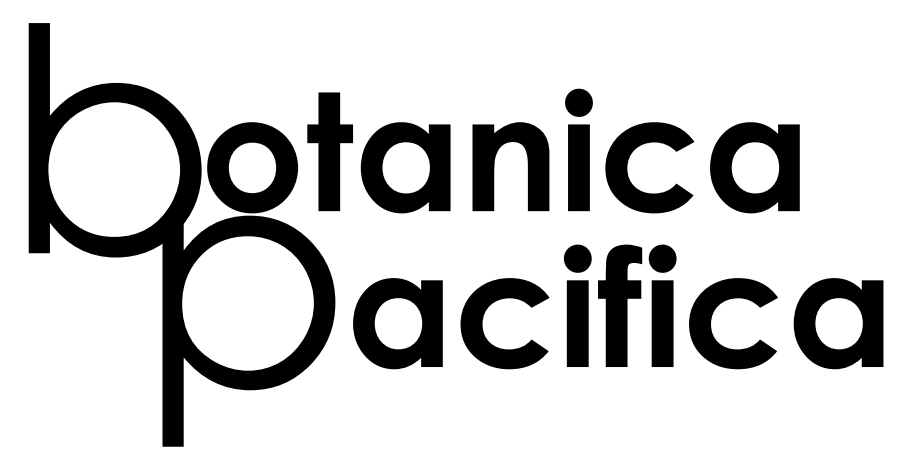

A JOURNAL OF PLANT SCIENCE
AND CONSERVATION

VOlUME 2, NO. 12013 
Botanica Pacifica

A JOURNAL OF PLANT SCIENCE AND CONSERVATION

VOLUME 2, NO. 12013
Botanica Pacifica (BP) publishes peer-reviewed, significant research of interest to a wide audience of plant versity, genetics, evolution, systematics), organization (molecular to ecosystem), and all plant groups and allied organisms (cyanobacteria, fungi, and lichens). Indexed by Russian Science Citation Index (http://elibrary.ru/title_about. asp?id $=34460$ ) scientists in all areas of plant biology (structure, function, development, di-
Botanica Pacifica (BP) пуболикует результаты исследований, прошедших независимую экспертизу и преАставАяющих значительный интерес широкому кругу ботаников во всех областях науки о растениях (структура, функции, развитие, разнообразие, генетика, эволюция и систематика), на всех уровнях организации живого (от молекулярного Ао экосистемного), по всем группам растений и родственным организмам (цианобактерии, грибы и кишайники). Индексируется Российским индексом научного цитирования (http://elibrary.ru/title_about. asp?id $=34460)$

\section{Chief editors:}

Pavel V. KRESTOV - Botanical Garden-Institute FEB RAS, Vladivostok, Russia

Peter G. GOROVOI - Pacific Institute of Bio-Organic Chemistry FEB RAS, Vladivostok, Russia

Vadim A. BAKALIN - Botanical Garden-Institute FEB RAS, Vladivostok, Russia

\section{Editorial board:}

Zumabeka AZBUKINA - Institute of Biology and Soil Science FEB RAS, Vladivostok, Russia Vyacheslav Yu. BARKALOV - Institute of Biology and Soil Science FEB RAS, Vladivostok, Russia Nadezhda I. BLOKHINA - Institute of Biology and Soil Science FEB RAS, Vladivostok, Russia Dmitrii E. KISLOV - Botanical Garden-Institute FEB RAS, Vladivostok, Russia

Andrei E. KOZHEVNIKOV - Institute of Biology and Soil Science FEB RAS, Vladivostok, Russia Yuri I. MANKO - Institute of Biology and Soil Science FEB RAS, Vladivostok, Russia Alexander M. OMELKO - Institute of Biology and Soil Science FEB RAS, Vladivostok, Russia Boris S. PETROPAVLOVSKII - Botanical Garden-Institute FEB RAS, Vladivostok, Russia Nina S. PROBATOVA - Institute of Biology and Soil Science FEB RAS, Vladivostok, Russia Larisa N. VASILYEVA - Institute of Biology and Soil Science FEB RAS, Vladivostok, Russia Yurii N. ZHURAVLEV - Institute of Biology and Soil Science FEB RAS, Vladivostok, Russia

\section{Editorial council:}

Konstantin S. BAIKOV - Institute of Soil Science and Agrochemistry SB RAS, Novosibirsk, Russia Elgene O. BOX - University of Georgia, Athens, USA

Victor V. CHEPINOGA - Irkutsk State University, Irkutsk, Russia

Klaus DIERSSEN - University of Kiel, Kiel, Germany

Nicolai B. ERMAKOV - Central Siberian Botanical Garden SB RAS, Novosibirsk, Russia

Andrew N. GILLISON - Center for Biodiversity Management, Yungaburra, Australia

Andrew M. GRELLER - Queens College, The City University of New York, New York, USA

Michael S. IGNATOV - Main Botanical Garden RAS, Moscow, Russia

Woo-Seok KONG - KyungHee University, Seoul, Republic of Korea

Nadezhda A. KONSTANTINOVA - Polar-Alpine Botanical Garden-Institute KSC RAS, Kirovsk, Russia Ilya B. KUCHEROV - Institute of Botany RAS, Saint-Petersburg, Russia

Victor Ya. KUZEVANOV - Botanical Garden of Irkutsk State University, Irkutsk, Russia

Yukito NAKAMURA - Tokyo University of Agriculture, Tokyo, Japan

Vladimir G. ONIPCHENKO - Moscow State University, Moscow, Russia

Dmitrii D. SOKOLOFF - Moscow State University, Moscow, Russia

Byung-Yun SUN - Chongbuk National University, Jeonju, Rep. Korea

Hideki TAKAHASHI - The Hokkaido University Museum, Hokkaido University, Sapporo, Japan Stephen S. TALBOT - US Fish and Wildlife Service, Anchorage, USA

Gennadii P. URBANAVICHUS - Institute of the Industrial Ecology Problems of the North KSC RAS, Apatity, Russia Pavel Y. ZHMYLEV - Moscow State University, Moscow, Russia

\section{Secretariat:}

Valentina A. KALINKINA - Botanical Garden-Institute FEB RAS, Vladivostok, Russia Eugenia V. BIBCHENKO - Botanical Garden-Institute FEB RAS, Vladivostok, Russia
(C) Botanica Pacifica 2012-2013. All rights reserved. No part of this publication may be reproduced, stored in a retrieval system or transmitted in any form or by any means without the written permission of the copyright holder. Requests for permission must be addressed to the editor.

C Botanica Pacifica 2012-2013. Bсе права защищены. Ни одна часть Аанного издания не может быть воспроизведена или передана в Аюбой форме и Аюббыми средствами (эмектронными, фотографическими или механическими), или представлена в поисковых системах без письменного разрешения держателя авторских прав, за которым следует обращаться к реАактору.

Издание зарегистрировано Федеральной службой по наАзору в сфере связи, информационных технологий и массовых коммуникаций Министерства связи и массовых коммуникаций Российской Федерации за № ПИ № ФС 77-52771

Journal Secretariat:

Botanica Pacifica

Botanical Garden-Institute FEB RAS

Makovskii Str. 142

Vladivostok 690024 RUSSIA

http://www.geobotanica.ru/bp

botanica.pacifica@icloud.com krestov@biosoil.ru v_bak@list.ru 


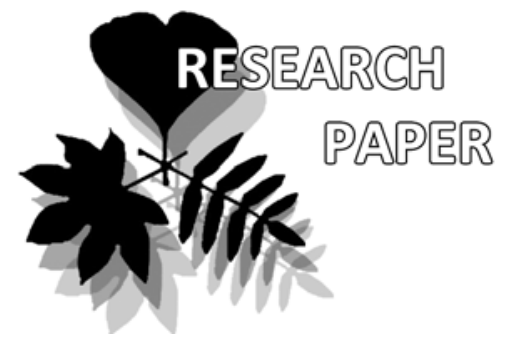

\title{
Mid-Holocene Vegetation and Environments on the Northeastern Coast of the Korean Peninsula
}

\author{
Tatiana A. Evstigneeva *, Natalia N. Naryshkina
}

Tatiana A. Evstigneeva *

melnikova@ibss.dvo.ru

Natalia N. Naryshkina

naryshkina@ibss.dvo.ru

Institute of Biology and Soil Science Vladivostok 690022 Russia

* corresponding author

Manuscript received: 17.09 .2012

Review completed: 29.01.2013

Accepted for publication: 13.02.2013

\begin{abstract}
A B S T R A C T
The pollen and spores from sediments of the core recovered from the shelf zone of the East Korea Bay, Eastern Sea (Sea of Japan) were studied. The vegetation of the northeastern coast of the Korean Peninsula was reconstructed based on pollen records. The most favorable conditions existed in mid-Holocene for the development of oak broadleaved forests. Fossil pollen grains of Quercus L. were studied with application of scanning electron microscope. Six types of fossil pollen grains were revealed: four types of them were assigned to deciduous oaks and two types to evergreen oaks. The deciduous oaks Q. dentata, Q. mongolica, and Q. serrata took significant part in vegetative associations of coast in mid-Holocene time.

Keywords

pollen, vegetation history, Holocene, East Asia, marine bottom sediments, Quercus
\end{abstract}

\section{P E 3 Ю M E}

Евстигнеева Т.А., Нарышкина Н.Н.

Растительность и климатические условия северо-восточного побережья Корейского полуострова в среднем голоцене

Изучены пыльца и споры из отложений колонки, отобранной в шельфовой зоне Восточно-Корейского залива (Японское море). Реконструирована растительность северо-восточного побережья Корейского полуострова. В среднем голоцене существовали самые благоприятные условия А^я развития Аубовых широколиственных месов. С помощью сканирующего электронного микроскопа изучены ископаемые пыльцевые зерна Quercus. Вылелены шесть типов ископаемых пыльцевых зерен: из них четыре типа относятся к Аистопадным дубам и Ава типа - к вечнозеленым. Аистопадные Аубы Q. mongolica, Q. dentata и Q. serrata принимали значительное участие в растительных ассоциациях побережья в среднеголоценовое время.

Ключевые слова

пыльца, история растительности, голоцен, Восточная Азия, морские Аонные отложения, Quercus

\section{INTRODUCTION}

Although the Holocene postglacial period was characterized by global climatic warming, the warmest conditions existed in the mid-Holocene (8000-4500 yr. BP). A study of fossil pollen and spores during this period is very important for understanding the modern vegetation history.

The Holocene vegetation history of the Korean Peninsula based on pollen analysis was previously described by Jo (1979, 1980, 1987), Yasuda et al. (1980), Chang \& Kim (1982), Yoon \& Jo (1996), Choi (1998), Lee \& Yim (2002), Yi et al. (2004, 2008), Fujiki \& Yasuda (2004), Chung (2006), Jun et al. (2010), and Chung et al. (2010). However, most investigations have been conducted in the southern part of peninsula, whereas our researches focused on the northeastern coast of the Korean Peninsula (Evstigneeva \& Naryshkina 2012). In this study we reconstruct the mid-Holocene vegetation on the north- east peninsula using pollen records. Additionally, we have identified species of Quercus L. fossil pollen grains using a scanning electron microscope (SEM) and clarified more detailed vegetation associations.

The northeastern coast of the Korean Peninsula is a temperate vegetation zone (Box \& Fujiwara 2012), where the climate of area is controlled by East Asian monsoon (Drozdov et al. 1989). During winter, high pressure air masses develop over inland Siberia, from which strong northwestern winds bring dry, cold air. The summer monsoon brings warm and abundant moisture from the ocean, and produces heavy rainfalls (average annual precipitation about $1500 \mathrm{~mm}$ ). The mean temperatures in July and in January are $+22{ }^{\circ} \mathrm{C}$ and $-21{ }^{\circ} \mathrm{C}$, respectively. The peninsula is mountainous, with heights of up to $2000 \mathrm{~m}$. Flat sites lie in the coastal zone. The modern vegetation of the area is warm-temperate deciduous broad-leaved forest consisting of Quercus mongolica, Q. aleina, Q. serrata, Q. dentata, Q. variabilis and Q. acutissima (Okumura 1974). Above 1400-1600 m, 


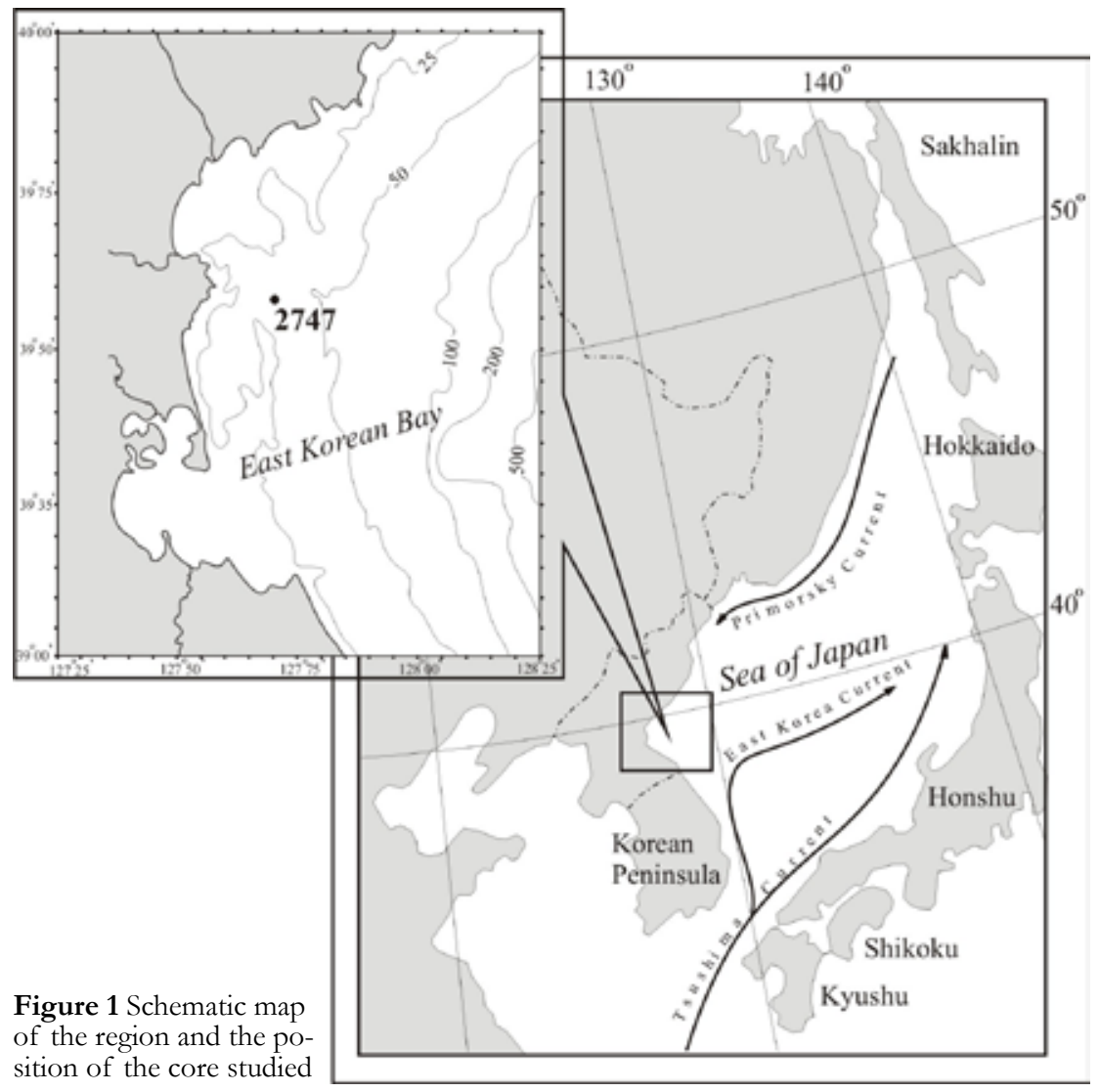

each type of Quercus fossil pollen were then calculated from the total sum of pollen grains Quercus.

\section{RES U LTS}

A variety of fossil pollen and spores were detected in seven samples from depths of 10 to 135 $\mathrm{cm}$. According to radiocarbon dating this interval corresponds to mid-Holocene. Palynomorphs were divided into arboreal pollen, nonarboreal pollen and spores.

Arboreal pollen: Abies, Picea, Pinus subgenus Haploxylon, P. subgenus Diploxylon, Ephedra, Ulmus, Castanea, Quercus, Alnus, Betula, Carpinus, Corylus, Juglans, Carya, Salix, Tilia, Acer, Syringa, Cornus.

Non-arboreal pollen: Caryophyllaceae, Chenopodiaceae, Polygonum subgenus Persicaria, Sanguisorba, Fabaceae, Apiaceae, Artemisia, Ambrosia and other Asteraceae, Poaceae, Typha, Polygala, Urticaceae.

Spores: Sphagnum, Lycopodium, Osmunda, Filicales monolete.

Arboreal pollen (Fig. 2) is dominated (55.2-82.5\%); the abundance of non-arboreal pollen (11.9$27.3 \%$ ) is slightly higher than that

the forest is coniferous, composed of Pinus koraiensis, P. densiflora, Picea koraiensis, Abies holophylla and Taxus cuspidata.

\section{MATERIALS AND METHODS}

Core 2747 (280 cm in length) was recovered during a 1989 cruise of the RV "Professor Bogorov", from the shelf zone of the East Korean Bay (Fig. 1). The sediments are clays and siltstones admixed with organic debris and coquina (Fig. 2). The radiocarbon dating of samples from the core was carried out in the Laboratory of geochemistry of isotopes and geochronology of Geological Institute RAS, Moscow with results shown in Table 1. According to Markov et al. (2008), micropaleontological analyses and radiocarbon dating restrict the sediments to the Holocene.

Fossil pollen grains were extracted from sediments using standard techniques (Pokrovskaya 1966), which included treatments with $10 \% \mathrm{KOH}$, mineral separation with a $\mathrm{KJ}$ and $\mathrm{CdJ}_{2}$ solution $\left(2.2 \mathrm{~g} / \mathrm{cm}^{3}\right)$, acetolysis. Pollen and spores were identified and counted with a light microscope in glycerine jelly. From 300 to 650 pollen grains and spores were counted for most samples. The percentage ratios for each taxon of pollen and spores were calculated from the total palynomorph sum.

Samples for observation were mounted for SEM (ZEISS EVO-40). The material was dehydrated in series of ethanol solutions (50, 70, $90 \%$ ), 15-20 min in each (Gapochka \& Chamara 1988). The samples were then set on sample stands and covered with gold under vacuum. Fifty fossil pollen grains of Quercus were identified at species level in a sample given at $60 \mathrm{~cm}$ depth. The percentage ratios for of spores (5.6-17.5\%). Pollen grains of deciduous trees make up 29.5-57.0\%, mostly at the expense of Quercus (21.8-44.2\%), Betula (0.9-6.7\%), Corylus (0.6-4.7\%), Alnus $(1.7-4.9 \%)$, and Juglans (0.3-3.1\%). The amount of conifer pollen varies from 10.2 to $47.0 \%$ constituted by Pinus subgenus Diploxylon (3.9-35.9 \%), P. subgenus Haploxylon (2.2-10.1 \%), Picea (1.8-3.9\%), and Abies (1.3-3.8\%). Ephedra, Ulmus, Castanea, Carpinus, Carya, Tilia, Acer, Syringa, Cornus, and Salix pollen comprised less than $1 \%$. Nonarboreal pollens are dominated by the Asteraceae (3.0-9.5 $\%$ ), mostly by Artemisia (2.7-7.8\%). Pollen grains of the Poaceae $(0.3-4.7 \%)$ and Chenopodiaceae $(0.8-1.7 \%)$ are less numerous. Pollen grains of the Caryophyllaceae, Polygonum subgenus Persicaria, Sanguisorba, Fabaceae, Apiaceae, Ambrosia, Typha, Polygala, and Urticaceae comprised less than $1 \%$. Spores were prevalent in members of the Filicales monolete (5.1-16.4 \%), whereas Sphagnum, Lycopodium, and Osmunda spores comprised less than $1 \%$.

Using a SEM, six types of fossil pollen grains of Quercus are identified in Holocene sediments of the southern part of the Japan Sea (Naryshkina \& Evstigneeva 2009). The electron microscopic study has shown that the Quercus pollen grain studied differ from each other by sculptural ele-

Table 1 Radiocarbon dates of samples from core

\begin{tabular}{c|c|c}
\hline Depth (cm) & Laboratory No. & Age (yr. BP) \\
\hline $35-42$ & GIN-13286 & $4440 \pm 110$ \\
\hline $120-130$ & GIN-13287 & $7750 \pm 90$ \\
\hline
\end{tabular}




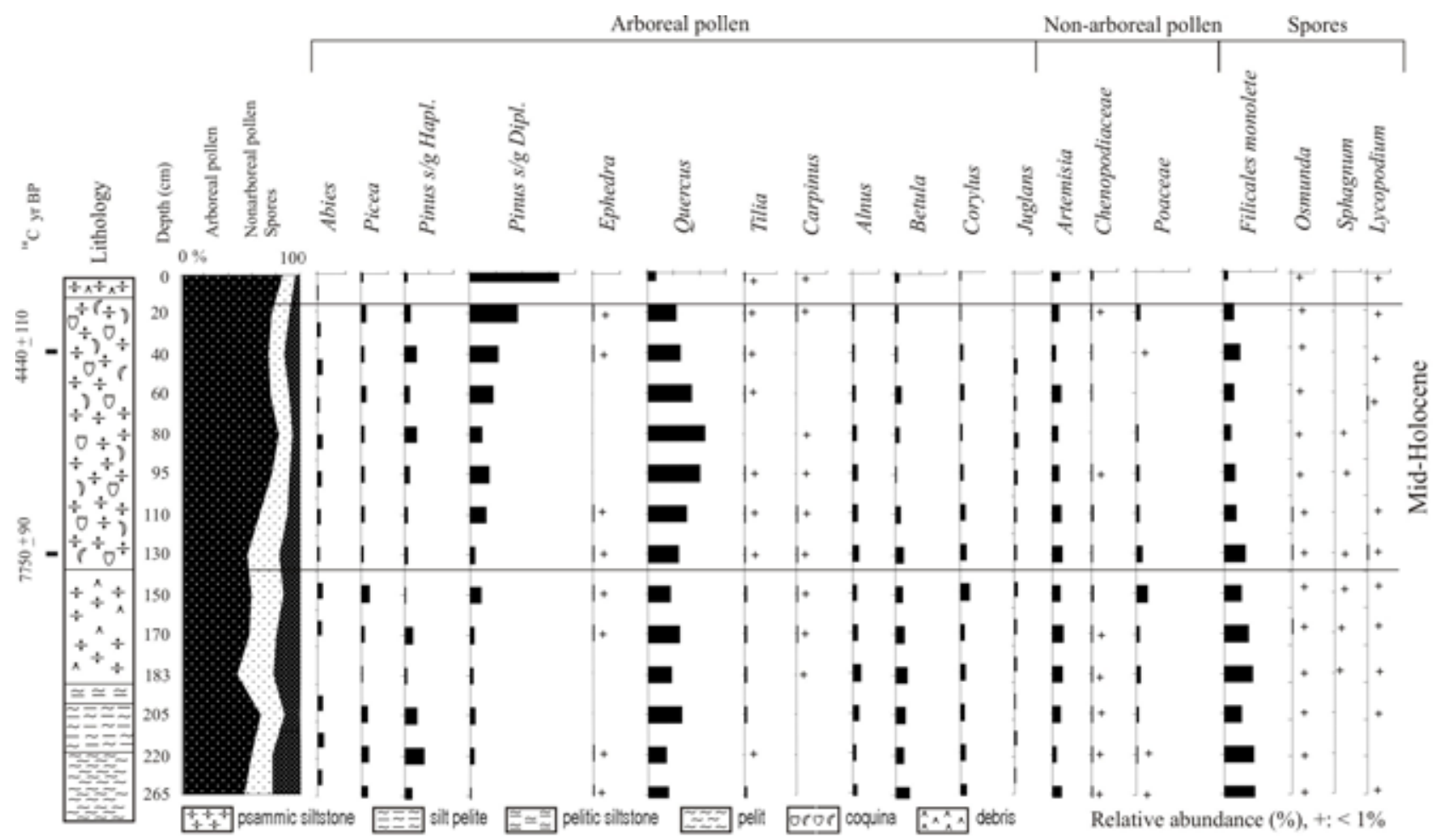

Figure 2 Palynological diagram of the main pollen types of core 2747

ments. All elements differ in size, form and their distribution on the grain surface. These elements may be combined in two groups: basal and secondary. The basal group consists of verrucae, scabrae, rugulae and rod-like elements, which form the sculptural type. Granules, rugules, spinula and perforation form the secondary group. These elements cover the basal ones or tectum.

Q. mongolica type - the sculpture is verrucate, formed by larger and smaller 0.5-07 $\mu \mathrm{m}$ rounded and ellipsoidal verrucae, evenly distributed on the surface of the pollen grain at a relatively short distance from each other. The surface of large verrucae is covered with small wrinkles and granules (Pl. 1: fig. $1 \mathrm{a}, \mathrm{b})$.

Q. variabilis type - the surface sculpture is verrucate, formed by large rounded verrucae $0.84-1.24 \mu \mathrm{m}$ in diameter. The verrucae are situated separately or fused in larger aggregates, forming elevations. Granules are discernable on the surface of the verrucae. The surface pattern does not differ near apertures (Pl. 1: fig. 2 a, b).

Q. serrata type - the sculpture is verrucate, formed by small $0.5-1.00 \mu \mathrm{m}$ in diameter and ultrafine rounded and ellipsoical verrucae, which are situated separately from each other and covered with granules and the smallest wrinkles. Perforations and granules are visible on the surface of the tectum (Pl. 1: fig. 3 a, b).

Q. dentata type - the sculpture is verrucate-granulate, formed by small $0.52-0.94 \mu \mathrm{m}$ in diameter and ultrafine verrucae, which are spheroidal-angular and nearly rectangular, flat, irregularly distributed over the pollen grain surface, denser on the apocolpium. Main sculptural elements are covered with distinct smallest granules (Pl. 1: fig. 4 a, b).

Q. sessillifolia type - the sculpture is rugulate-echinate, formed by large wrinkles separated by a depression. Gra- nules and small wrinkles are visible on the surface of large wrinkles (Pl. 1: fig. 5 a, b).

Q. glanca type - of sculpture is presented by unique partially fused vertical rod-like elements. The sculpture is formed by rhomboidal, oval, and elongated elements, covered with numerous fine granules. The texture is perforated (Pl. 1: fig. $6 \mathrm{a}, \mathrm{b})$.

Four of them were assigned to deciduous oaks $(Q . m o n$ golica, Q. variabilis, Q. serrata and Q. dentata types) and two assigned to evergreen oaks (Q. glauca and Q. sessillifolia types).

The results of SEM pollen analysis are shown in Fig. 3. Most pollen grains belonged to the $Q$. dentata type (36\%) and $Q$. mongolica type (32\%). The ratio of $Q$. serrata type was $26 \%$; that of $Q$. variabilis type was $4 \%$, that of $Q$. sessillifolia type was $1 \%$ and that of Q. glauca type was $1 \%$. Pollen of evergreen oaks Q. glauca and Q. sessillifolia were recognized in this sample. However, today evergreen $Q$. glauca grows only at the southernmost Korean Peninsula, while Q. sessillifolia occurs in evergreen forests of the Japanese Islands and China (Menitskii 1984). Most likely, pollen of these evergreen Quercus species was transported into sediments by wind or water streams from long-distance.

To south of the core 2747, pollen grains of Quercus were identified in mid-Holocene sediments of Lake Hyangho located in the northeastern coast area of the Korean Peninsula (Fujiki \& Yasuda 2004). Most pollen grains of Quercus belonged to the $Q$. variabilis type $(36.2 \%)$ and $Q$. dentata type $(32.6 \%)$. The percentage ratio of $Q$. serrata type was $13.8 \%$, that of $Q$. aliena type was $8.7 \%$, that of $Q$. crispula type was $1 \%$, and that of $Q$. acutissima type was $1 \%$ (Fig. 3). All these Quercus types are assigned to deciduous oaks.

To north of the core 2747, fossil pollen grains of Quercus were identified in mid-Holocene sediments of the 

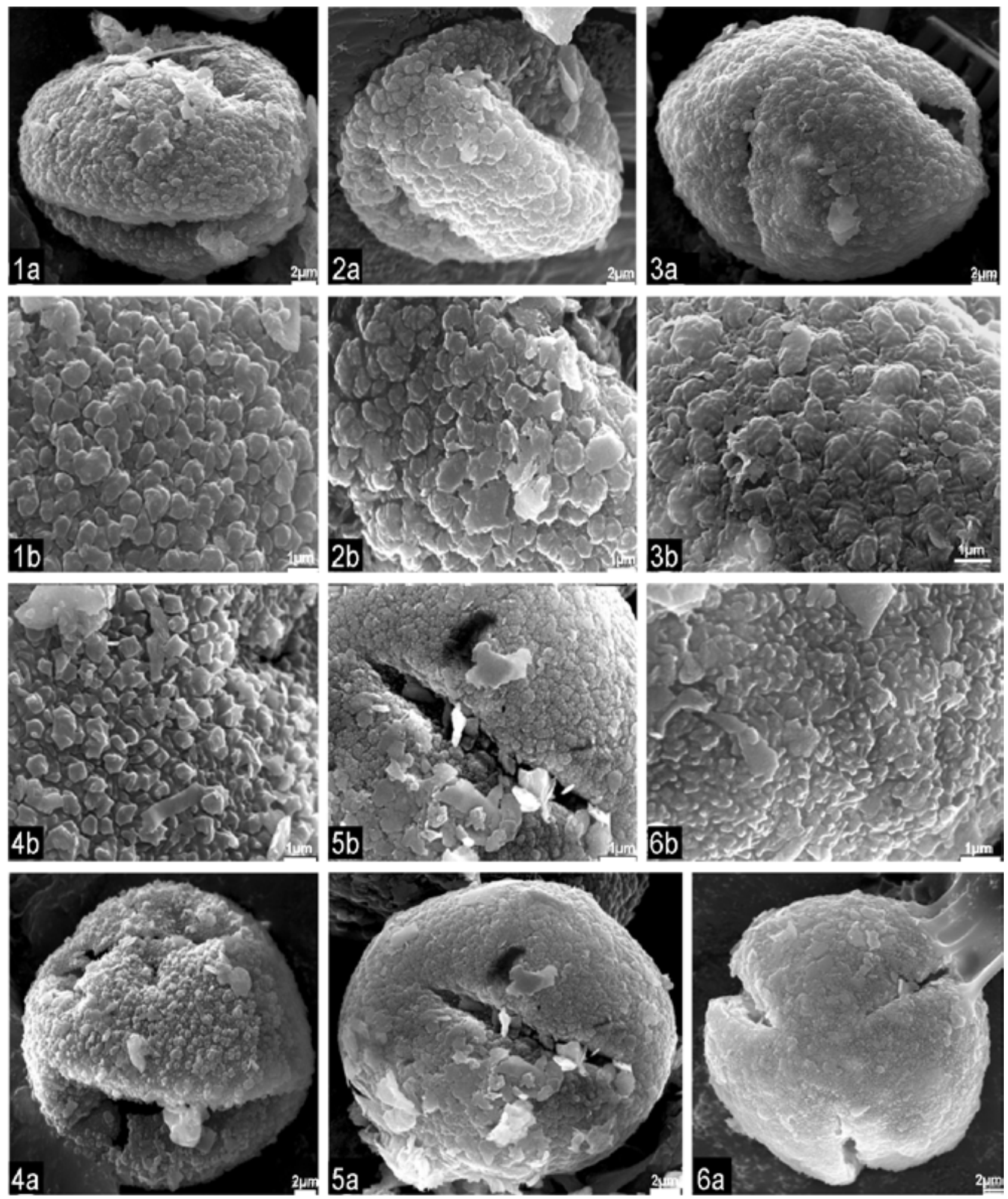

Plate 1 Fossil Quercus pollen types from Holocene sediments of East Korean Bay.

Fossil pollen grains: $1-$ Q. mongolica type (a - general appearance, $\times 3740$, SEM; b - part of sculpture, $\times 10$ 000, SEM); $2-Q$. variabilis type (a - general appearance, $\times 4340$, SEM; $b-$ part of sculpture, $\times 10000$, SEM); $3-Q$. serrata type (a- general appearance, $\times 2300$, SEM; b - part of sculpture, $\times 10000$, SEM); $4-Q$. dentata type $(\mathrm{a}-$ general appearance, $\times 3740$, SEM; $b-$ part of sculpture, $\times 10000$, SEM); 5 - (Q. sessillifolia type (a - general appearance, $\times 4340$, SEM; b - part of sculpture, $\times 10000$, SEM); $6-Q$. glauca type $(a-$ general appearance, $\times 2300$, SEM; $b-$ part of sculpture, $\times 10000$, SEM) 


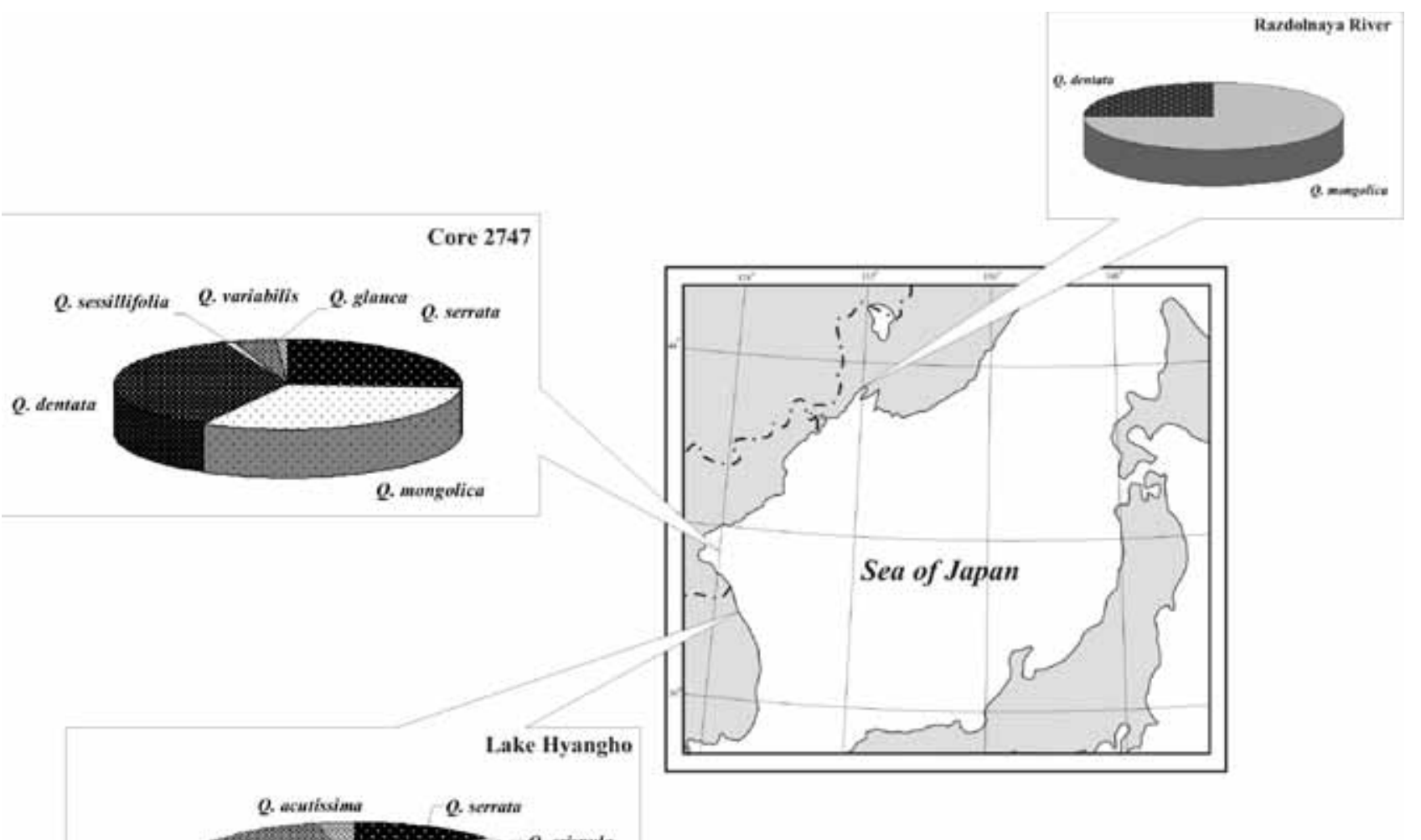

Razdolnaya River valley (Southern Primory'e, Far East of Russia) (Naryshkina 2005). Two types of deciduous oaks (Q. mongolica and $Q$. dentata types) were recognized. The appearance ratio of the Q. mongolica type was $75 \%$, and $Q$. dentata type was $25 \%$ (Fig. 3).

\section{DISCUSSION}

The palynological records reveal vegetation on northeast of the Korean Peninsula during the Holocene. This paper focuses mainly on the vegetation and environments of mid-Holocene (8000-4500 yr BP). The high proportion of arboreal pollen (about $82.5 \%$ ) and negligible amounts of non-arboreal pollen and spores (Fig. 2) indicate a closed forest. During this period, Quercus-dominated deciduous broadleaved forests with ferns flourished on the neighboring hills and mountainous area. The deciduous oaks Quercus mongolica, Q. dentate, and Q. serrata occupied a significant part of vegetation associations of the coast. Other deciduous tree species, such as Corylus, Alnus, Juglans, Castanea, Carpinus, Carya, Tilia, Acer, Syringa, Cornus, Ulmus, and Salix, are also represented. The conifer forests consisted of Abies, Picea, Pinus subgenera Diploxylon and Haploxylon with coldtolerant Betula on mountain tops. Herbaceous steppe and meadow vegetation consisted of Asteraceae, Chenopodiaceae, Urticaceae, Ephedra, Caryophyllaceae, Polygonum subgenus Persicaria, Sanguisorba, Fabaceae, Apiaceae, Polygala, and Poaceae.

The deciduous Quercus forests prevailed over a wide range of the east coast of the Korean peninsula during this

Figure 3 The percentages of fossil Quercus pollen types in midHolocene sediments

time (Yasuda et al. 1980, Jo 1987, Fujiki \& Yasuda 2004, Yi et al. 2008). A high concentration of $Q$. dentata type (Fig. 3) allows to assume that this species of oak, probably, was more widespread along the west coast of the Sea of Japan than it is today.

Whereas, in southeastern and central regions of the Korean Peninsula, evergreen broad-leaved trees, such as Quercus subgenus Cyclobalanopsis and Castanopsis appeared. Alnusdominated deciduous forests covered extensive lowlands of the west coast of the Korean peninsula (Yasuda et al. 1980, Jo 1987, Fujiki \& Yasuda 2004, Yi et al. 2008).

In China, in mid-Holocene time, the northern limit of broad-leaved evergreen forests was $200 \mathrm{~km}$ further north than present (Winkler \& Wang 1993, Yafeng et al. 1993, Yu et al. 1998, 2000, Xiaoqiang et al. 2004, Jiang et al. 2006, Tarasov et al. 2006). Temperate deciduous forests occurred $800 \mathrm{~km}$ north of its present limit, in the zone occupied today by cool mixed forest and taiga. In northwestern China, the area of desert and steppe vegetation was reduced compared to present.

In mid-Holocene, broad-leaved deciduous forests also have been extensively developed in southern part of the Russian Far East (Karaulova et al. 1978, Golubeva \& Karaulova 1983, Kuz'mina et al. 1987, Verkhovskaya \& Kundyshev 1995, Korotkii et al. 1996). Oak forests reached the latitudes $50-52^{\circ} \mathrm{N}$ along the coast of the Sea of Japan and the Ussuri River valley. Vegetation zones were $600-700 \mathrm{~km}$ north of today, and the mountains up to $700 \mathrm{~m}$ higher.

Deciduous broad-leaved forests dominated by Quer- 
cus, Ulmus and Juglans were spread in the south-east of the Sakhalin Island (Mikishin \& Gvozdeva 1996). Small groves of broadleaf trees grew near the coast in northern Sakhalin (Mikishin \& Gvozdeva 2007).

Quercus subgenus Lepidobalanus and Fagus were co-dominant taxa in northeastern Japan, and Quercus subgenus Cyclobalanopsis and Castanopsis, in southwestern Japan (Tsukada 1988). Temperate deciduous forests were predicted at elevations up to $500 \mathrm{~m}$ higher than today (Takahara et al. 2000). Another characteristic feature is that, in mid-Holocene time, the subalpine and temperate coniferous forests were completely separated into three distinct regions: southwestern Japan, the central mountains, and Hokkaido.

Additionally, the difference between two regions along the Sea of Japan in this time should be mentioned. Fagus pollen grains do not appear in Korea but appear in high percentages in Japan (Tsukada 1982). Hence, the climate of the Japan aspect was more humid. Most likely it has been influenced by the warm Tsushima Current, which, on southern part of the Sea of Japan $8000 \mathrm{yr}$ BP, became similar to the modern situation (Ujiie \& Ujiie 1999, Oba 1983).

Thus, shifts of vegetation zones reflect a significant difference between the warmest climatic conditions existed in the mid-Holocene and recent climates of southern part of East Asia.

In the Northern hemisphere, the summer solar radiation peaked at about $9000 \mathrm{yr}$ BP. It was $7 \%$ higher than at present (Kutzbach 1981, Neftel et al. 1982, Lorius et al. 1985). As a result, the seasonal range of temperatures increased considerably. The summers were very warm, and winters cold (Krassilov et al. 1985, Kutzbach \& Street-Perrott 1985, An et al. 2000). Therefore a majority of thermophilic plants was unable to be sustained.

In the mid-Holocene, the climate became milder with warmer winters. More proportional solar radiation per season led to a decreased annual range of temperatures: July temperatures slightly decreased, and January temperatures increased (Prell \& Kutzbach 1987). Mean annual temperature in East Asian was $2-5{ }^{\circ} \mathrm{C}$ higher than nowadays (Yasuda 1982, Golubeva \& Karaulova 1983, Sohn 1984, Tsukada 1986, Winkler \& Wang 1993, Verkhovskaya \& Kundyshev 1995, Kuzmin 1995, Korotkii et al. 1996, Mikishin \& Gvozdeva 1996, Yi et al. 2003). However, the climate of this time was cooler than that of warm epochs of the Pleistocene (Golubeva \& Karaulova 1983). Mid-Holocene warming has also been observed in pollen analyses in the East Asian region (Yasuda 1982, Golubeva \& Karaulova 1983, Tsukada 1986, Winkler \& Wang 1993, Verkhovskaya \& Kundyshev 1995, Kuzmin 1995, Korotkii et al. 1996, Yi et al. 2003). This climatic event correlates with the Atlantic phase of the scheme Blytt-Sernander modified by Khotinskii (1977).

Mid-Holocene hypsithermal conditions had a profound influence on the whole environment. The temperature of the Sea of Japan water surface was $1-2{ }^{\circ} \mathrm{C}$ higher in that time than at present (Pletnev 1985). Warm waters of the Tsushima Current reached the northern coast of Hokkaido Island and penetrated into the Sea of Okhotsk through the La Perouse Strait (Taira 1992, Taira \& Lutaenko 1993). The East Korean Current influenced the coast of the Primorkii
Region of Russia up to $40^{\circ} \mathrm{N}$ pushing off cold waters of the Primorskii Current (Korotkii et al. 1996). The sea level in the area of the Japanese Islands was 2-6 m higher than the modern level (Fujii \& Fuji 1967, Sakaguchi 1983, Umitsu 1991; Mikishin \& Gvozdeva 1996, Hwang 1998, Korotkii et al. 1996, Markov et al. 2008). Therefore, large areas of coastal lowlands were submerged by sea water.

Thus, palynological and paleogeographical data studied here indicate that in mid-Holocene the conditions in southern part of East Asia were wetter and warmer than those of present in most areas of East Asian region.

\section{ACKNOWLEDGMENTS}

We are grateful to Dr. F. R. Likht (V. I. Il'ichev Pacific Oceanological Institute, Far East Branch, Russian Academy of Sciences, Vladivostok), who provided the material for this study. The study was supported by the Russian Foundation for Basic Research (project no. 12-05-31201) and the Presidium of the Russian Academy of Sciences and Far East Branch, Russian Academy of Sciences (12-I-P28-01).

\section{LITERATURE CITED}

An, Z., S. C. Porter, J. E. Kutzbach, W. Xihao, W. Suming, L. Xiaodong \& Z. Weijian 2000. Asynchronous Holocene optimum of the East Asian monsoon. Quaternary Science Reviens 19:743762.

Box, E. O. \& K. Fujiwara 2012. A comparative look at bioclimatic zoation, vegetation types, tree taxa and species richness in Northeast Asia. Botanica Pacifica 1:5-20.

Chang, C. H. \& C. M. Kim 1982. Late Quaternary vegetation in the lakes of Korea. Korean Journal of Botany 25:37-53.

Chang, P. J., S. Yi \& S. J. Lee 2010. Palynological implication of Holocene vegetation and environment in Pyeongtaek wetland, Korea. Quaternary International 227:68-74.

Choi, K. R. 1998. The post-glacial vegetation history of the lowland in Korean Peninsula. Korean Journal of Ecology 21:169-174.

Chung C.H. 2006. Vegetation and climate changes during the Late Pleistocene to Holocene inferred from pollen record in Jinju area, South Korea. - Geosciences Journal 10 (4): 423-431.

Chung, C. H., H. S. Lim \& H. J. Lee 2010. Vegetation and climate history during the late Pleistocene and early Holocene from pollen record in Gwangju area, South Korea. Quaternary International 227:61-67.

Drozdov, O. A., V. A. Vasiliev \& N. V. Kobysheva 1989. Climatology. Leningrad, Gidrometeoizdat, 568 pp. (in Russian). [АрозАов О. А., Васильев В. А., Кобышева Н. В. 1989. Климатология. Аенинград: Гидрометеоиздат. 568 с.]

Evstigneeva, T. A. \& N. N. Naryshkina 2012. Holocene vegetation changes on the north-eastern coast of the Korean Peninsula based on the palynological data. Acta Palaeobotanica 52(1):147155.

Fujii, S. \& N. Fuji 1967. Postglacial sea level in the Japanese Islands. Journal Geosciences 10:43-51.

Fujiki, T. \& Y. Yasuda 2004. Vegetation history during the Holocene from Lake Hyangho, northeastern Korea. Quaternary International 123-125: 63-69.

Gapochka, G. P. \& L. P. Chamara 1988. Modern methods of the analysis of sporoderm using electron microscopy: study guide. Izdatel'stvo MGU, Moscow, 41 pp. (in Russian). [Гапочка Г.П., Чамара А.П. 1988 Современные методы исследования спородермы с применением электронной микроскопии (методическое пособие). Москва: Издательство МГУ. 41 с.]

Golubeva, L. V. \& L. P. Karaulova 1983. Vegetation and Climatostratigraphy of the Pleistocene and Holocene of the Southern Far East of the USSR. Nauka, Moscow, 144 pp. (in Russian). [Голуб́ева А.В., Караулова А.П. 1983. Растительность и 
климатостратиграфия плейстоцена и голоцена юга Аальнего Востока СССР. Москва: Наука. 1983. 144 с.].

Hwang, S. I. 1998. The Holocene depositional environment and sea-level change at the Ilsan area. Geographical Journal of Korea 33 (2):143-163.

Jiang, W., Z. Guo, X. Sun, H. Wu, G. Chu, B. Yuan, C. Hatte \& J. Guiot 2006. Reconstruction of climate and vegetation changes of Lake Bayanchagan (Inner Mongolia): Holocene variability of the East Asian monsoon. Quaternary Research 65:411-420.

Jo, W. 1979. Palynological studies on post glacial age in eastern coastal region, Korea Peninsula. Quarterly Journal of Geography 33:23-35.

Jo, W. 1980. Holocene sea-level changes on the east coast of Korean Peninsula. Geographic Review 53:317-328.

Jo, W. R. 1987. Alluvial plain of Korea. Kyohakyonkusa, Seoul, 241 Pp.

Jun, C. P., S. Yi \& S. J. Lee 2010. Palynological implication of Holocene vegetation and environment in Pyeongtaek wetland, Korea. Quaternary International 227:68-74.

Karaulova, L. P., A. M. Korotkii \& I. G. Gvozdeva 1978. Spatio-temporal evolution of plant communities of the Holocene in the Primorye. In: Palynological studies in the Far East (M.P. Grichuk \& A.M. Korotkii, eds.), pp. 91-100, Izdatel'stvo Dal'nevostochnogo Nauchnogo Tsentra Akademii Nauk SSSR, Vladivostok (in Russian). [Караулова А.П., Короткий A.M., Гвоздева И.Г. 1978. Пространственно-временная эволюция растительных сообществ голоцена на территории Приморья // Палинологические исследования на Аальнем Востоке / поА реА. М.П. Гричука и А.М. Короткого. ВАадивосток: ИзА-во АВНЦ АН СССР. С. 91-100].

Korotkii, A. M., T. A. Grebennikova, V. S. Pushkar, N. G. Razjigaeva, V. G. Volkov, L. A. Ganzei, L. M. Mokhova, V. B. Bazarova \& T. R. Makarova 1996. Climatic changes on the south of Russian Far East in the late Cenozoic. Izdatel'stvo Tikhookeanskogo Instituta Geografii Dal'nevostochnogo Otdeleniya Rossiiskoi Akademii Nauk, Vladivostok, 57 pp. (in Russian). [Короткий А.М., Гребенникова Т.А., Пушкарь В.С., Разжигаева Н.Г., Волков В.Г., Ганзей А.А., Мохова А.М., Базарова В.Б., Макарова Т.Р. 1996. Климатические смены на территории юга АаАьнего Востока в позднем кайнозое. ВАадивосток: Издательство ТИГ АВО РАН. 57 с.].

Khotinskii, N. A. 1977. Holocene of Northern Eurasia. Nauka, Moscow, 200 pp. (in Russian). [Хотинский Н.A. 1977. Голоцен Северной Евразии. Москва: Наука. 200 с.].

Krassilov, V. A., V. A. Zubakov, V. I. Shul'diner \& V. I. Remizovskii 1985. Ecostratigraphy: Theory and Methods. Izdatel'stvo Dal'nevostochnogo Nauchnogo Tsentra Akademii Nauk SSSR, Vladivostok, 148 pp. (in Russian). [Красилов В.А., Зубаков В.А., Шульдинер В.И., Ремизовский В.И. 1985.Экостратиграфия. Теория и методы. ВАаАивосток: Издательство АВНЦ АН CCCP. 148 c.]

Kutzbach, J. E. 1981. Monsoon climate of the early Holocene: Climate experiment using the earth's orbital parameters for 9000 years ago. Science 214(4516):59-61.

Kutzbach, J. E. \& F. A. Street-Perrott 1985. Milankovitch Forcing of Fluctuations in the Level of Tropical Lakes from 10 to $0 \mathrm{ka}$ B.P. Nature 317:130-134.

Kuz'min, Y. V. 1995. Paleogeography of the Peter the Great Bay Coast during the Holocene Optimum (5000-8000 Years Ago) In: Integrated Study of the Holocene Sections on the Peter the Great Bay Coast (Sea of Japan) (Y. V. Kuz'min, ed.), pp. 44-70. Izdatel'stvo Tikhookeanskogo Instituta Geografii Dal'nevostochnogo Otdeleniya Rossiiskoi Akademii Nauk, Vladivostok (in Russian). К Кузьмин Я.В. 1995. Памеогеография побережья залива Петра Великого в оптимум голоцена (5000-8000 А.н.) // Комплексное изучение разрезов голоценовых отложений побережья залива Петра Великого (Японское море) / Под реА. Я.В. Кузьмина. ВАаАивосток: ИзАательство ТИГ АВО РАН. С. 44-70].

Kuz'mina, N. N., G. M. Shumova, E. I Polyakova \& G. N. Nedesheva 1987. Paleogeographic reconstruction of Holocene northwest coast and shelf of the Sea of Japan. Izvestiya Akademii Nauk SSSR. Seriya geograficheskaya 4:78-89 (in Russian). [Кузьмина Н.Н., Шумова Г.М., Полякова Е.И., Нелешева Г.Н. 1987. Палеогеографические реконструкции голоцена северо-западного побережья и шельфа
Японского моря // Известия Академии наук СССР. Серия географическая. № 4. С. 78-89].

Lee, W. C. \& Y.-J. Yim 2002. Plant Geography. Kangwon National University Press, Chuncheon, 412 pp.

Lotius, C., J. Jousel \& R. Ritz 1985. A 150,000-year climatic record from Antarctic ice. Nature 316(6029):591-596.

Markov, Y. D., F. R. Likht, A. N. Derkachev, I. V. Utkin, A. I. Botsul, V. S. Pushkar, E. D. Ivanova, T. A. Evstigneeva \& G. A. Evseev 2008. Sediments of buried paleovalleys on the shelf of East Korean Bay as indicators of Holocene paleogeographic settings. Russian Journal of Pacific Geology 3:74-93 (in Russian). Марков Ю.А., Аихт Ф.Р., Аеркачев А.Н., Уткин И.В., БоцуА А.И., Пушкарь В.С., Иванова Е.А., Евстигнеева Т.А., Евсеев Г.А. 2008. ОсаАки затопленных Аолин прибрежной части шельфа Восточно-Корейского залива - индикаторы палеогеографических условий в голоцене // Тихоокеанская геология. № 3. С. 74-93].

Menitskii, Y. L. 1984. Oaks of Asia. Nauka, Leningrad, 316 pp. (in Russian). [Меницкий Ю.А. 1984. Аубы Азии. АенинграА: Наука. 316 с.].

Mikishin, Y. A. \& I. G. Gvozdeva 1996. The natural evolution in the south-eastern part of Sakhalin Island in the Holocene. Izdatel'stvo Dal'nevostochnogo Gosudarstvennogo Universiteta, Vladivostok, 130 pp. (in Russian). [Микишин Ю.А., Гвоздева И.Г. 1996. Развитие природы юго-восточной части острова Сахалин в голоцене. ВАаАивосток: ИзА-во АВГУ, 130 с.].

Mikishin, Y. A. \& I. G. Gvozdeva 2007. Paleogeography of northeastern coast of Sakhalin in Holocene. In: Global change studies in the Far East (P. Y. Baklanov \& L. A. Ganzey, eds.), pp. 82-93. Dal'nauka, Vladivostok (in Russian). [Микишин Ю.А., Гвоздева И.Г. 2007. Палеогеография побережья северовосточного Сахалина в голоцене // Изучение глобальных изменений на Аальнем Востоке / под ред. П.Я. Бакланова и А.А. Ганзея. ВАадивосток: Аамьнаука. С. 82-93].

Naryshkina, N. N. 2005. Pollen grains of some species of genus Quercus as possible indicator of Holocene paleoclimate of the Far East Region In: Modern paleontology: classic and newest methods (A. Y. Rozanov et al., eds.), pp. 210-215. Izdatel'stvo Paleontologicheskogo Instituta Rossiiskoi Akademii Nauk, Moscow (in Russian). [Нарышкина Н. Н. 2005. Пыльцевые зерна некоторых видов рода Quercus как возможный индикатор паАеоклимата голоцена Аальнего Востока // Современная палеонтология: классические и новейшие методы / поА реА. А. Ю. Розанов и ар. Москва: Иза-во ПИН РАН. С. 210-215].

Naryshkina, N. N. \& T. A. Evstigneeva 2009. Sculpture of pollen grains of Quercus L. from the Holocene of the South of the Sea of Japan. Paleontological Journal 43(10):1309-1315.

Neftel, A., H. Oeschger \& J. Schwander 1982. Ice core sample measurements give atmospheric CO2 content during the past 40,000 yr. Nature 295(5831):391-394.

Oba, T. 1983. Paleoenvironment of the Japan Sea since the last glacial age. A Monthly Earth 5:37-46.

Okumura, S. 1974. Forest of Korean Peninsula. Doi Ringaku Shinkokai, Tokio, 309 pp.

Pletnev, S. P. 1985. Stratigraphy of bottom sediments and paleogeography of the Sea of Japan in the Late Quaternary time. Izdatel'stvo Dal'nevostochnogo Nauchnogo Tsentra Akademii Nauk SSSR, Vladivostok, 112 pp. (in Russian). [Плетнев С.П. 1985. Стратиграфия Аонных отложений и палеогеография Японского моря в позднечетвертичное время. ВАадивосток: Издательство АВНЦ АН СССР. 112 c.].

Pokrovskaya, I. M. 1966. Paleopalynology. Nedra, Leningrad, 261 pp. (in Russian). [Покровская И.М. 1966. Палеопалинология. Менинград: Недра. 261 с.].

Prell, W. L. \& J. E. Kutzbach 1987. Monsoon variability over the past 150000 years. Journal of Geophysics Research 92:8411-8425.

Sakaguchi, Y. 1983. Warm and cold stages in the past 7600 years in Japan and their global correlation - especially on climatic impacts to the global Sea level changes and the ancient Japanese history. Bulletin of the Department of Geography of the University of Tokyo 15:1-31.

Sohn, P. K. 1984. The paleoenvironment of middle and upper Pleistocene Korea. In: The evolution of the East Asian environment. 
Vol. 4. (R. P. Whyte, ed.), pp. 877-893, University of Hong Kong Press, Hong Kong.

Taira, K. 1992. Holocene palaeoceanographic changes in Japan. Report Taisetsuzan Institute Science 27:1-7.

Taira, K. \& K. A. Lutaenko 1993. Holocene Palaeoceanographic Changes in the Sea of Japan. Report Taisetsuzan Institute Science 28:65-70.

Takahara, H., S. Sugita, S. P. Harrison, N. Miyoshi, Y. Morita \& T. Uchiyama 2000. Pollen-based reconstructions of Japanese biomes at 0, 6000 and 18,000 14C yr BP. Journal of Biogeography 27:665-683

Tarasov, P., G. Jin \& M. Wagner 2006. Mid-Holocene environmental and human dynamics in northeastern China reconstructed from pollen and archaeological data. Palaeogeography, Palaeoclimatology, Palaeoecology 241(2):284-300.

Tsukada, M. 1982. Late-Quaternary shift of Fagus distribution. Botanical Magazine Tokyo 95:203-217.

Tsukada, M. 1986. Vegetation in prehistoric Japan: The last 20,000 years. In: Windows on the Japanese past: Studies in archeology and prehistory (R. J. Pearson, ed.), pp. 11-56. University of Michigan Press, Michigan.

Tsukada, M. 1988. Japan. In: Vegetation history (B. Huntley \& T. Webb III, eds.), pp. 459-518, Kluwer Academic Publishers, Dordrecht.

Ujiie, H. \& Y. Ujiie 1999. Late Quaternary course changes of the Kuroshio Current in the Ryukyu Arc region, northwestern Pacific Ocean. Marine Micropaleontology 37:23-40.

Umitsu, M. 1991. Holocene sea-level changes and coastal evolution in Japan. Quaternary Research 30(2):187-196.

Verkhovskaya, N. B. \& A. S. Kundyshev 1995. Vegetation of the Peter the Great Bay Coast during the Holocene Optimum. In: Integrated Study of the Holocene Sections on the Peter the Great Bay Coast (Sea of Japan) (Y. V. Kuz'min, ed.), pp. 8-17. Izdatel'stvo Tikhookeanskogo Instituta Geografii Dal'nevostochnogo Otdeleniya Rossiiskoi Akademii Nauk, Vladivostok (in Russian). [Верховская Н.Б., Кундышев А.С. 1995. Растительность побережья залива Петра Великого в оптимальную фазу гомоцена // Комплексное изучение разрезов голоценовых отложений побережья залива Петра Великого (Японское море) / под ред. Я. В. Кузьмина. ВАадивосток: ТИГ АВО PAH. C. 8-17].

Winkler, M. G. \& P. K. Wang 1993. The Late-Quaternary Vegetation and Climate of China. In: Global Climates since the Last Gla- cial Maximum (H.E. Wright et al., eds.), pp. 221-264. University of Minnesota Press, Minneapolis.

Xiaoqiang, L., Z. Jie, S. Ji, W. Chengyu, Z. Hongli \& S. Qianli 2004. Vegetation history and climatic variations during the last $14 \mathrm{ka} B P$ inferred from a pollen record at Daihai Lake, north-central China. Review of Palaeobotany and Palynology 132: 195-205.

Yafeng, S., K. Zhaozheng, W. Sumin, T. Lingyu, W. Fubao, Y. Tandong, Z. Xitao, Z. Peiyuan \& S. Shaohua 1993. Mid-Holocene climates and environments in China. Global and Planetary Change 7:219-233.

Yasuda, Y., M. Tsukada, J. M. Kim, S. T. Lee \& Y. J. Yim 1980. The environment changes and the agriculture origin in Korea. Japanese Ministry of Education Overseas Research Reports, pp. 1-19.

Yasuda, Y. 1982. Pollen analytical study of the sediment from the Lake Mikata in Fukui Prefecture, Central Japan. Quaternary Research 21:255-271.

Yi, S., Y. Saito, Q. Zhao \& P. Wang 2003. Vegetation and climate changes in the Changjiang (Yangtze River) Delta, China, during the past 13,000 years inferred from pollen records. Quaternary Science Reviews 22:1501-1519.

Yi, S., S. I. Nam, S. W. Chang \& J. H. Chang 2004. Holocene environmental changes in the tidal sediments of west coast of South Korea inferred from pollen records. Journal of the Geological Society of Korea 40:213-225.

Yi, S., J.-Y. Kim, D.-Y. Yang, K.-C. Oh \& S.-S. Hong 2008. Midand Late-Holocene palynofloral and environmental change of Korean central region. Journal of the Geological Society of Korea 40:213-225.

Yoon, S. O. \& W. R. Jo 1996. The late Quaternary environmental in Youngyang Basin, southeastern part of Korea Peninsula. The Korean Geographical Society 31:447-468.

Yu, G., I. C. Prentice, S. P. Harrison \& X. Sun 1998. Pollen-based biome reconstructions for China at $0 \mathrm{ka}$ and $6 \mathrm{ka}$. Journal of Biogeography 25:1055-1069.

Yu, G., X. Chen, J. Ni, R. Cheddadi, J. Guiot, H. Han, S. P. Harrison, C. Huang, M. Ke, Z. Kong, S. Li, W. Li, P. Liew, G. Liu, J. Liu, Q. Liu, K.-B. Liu, I. C. Prentice, W. Qui, G. Ren, C. Song, S. Sugita, X. Sun, L. Tang, E. van Campo, Y. Xia, Q. Xu, S. Yan, X. Yang, J. Zhao \& Z. Zheng 2000. Palaeovegetation of China: a pollen data-based synthesis for the mid-Holocene and last glacial maximum. Journal of Biogeography 27:635-664. 